\title{
TELAAH BAHAN AJAR BIOLOGI MELALUI LEARNING COMMUNITY PADA PEMBELAJARAN KOLABORATIF VIRTUAL DI MASA PANDEMI COVID-19
}

\author{
Muhfahroyin ${ }^{1}$ \\ Agil Lepiyanto $^{2}$ \\ 1, 2) Pendidikan Biologi Universitas Muhammadiyah Metro \\ E-mail: ${ }^{1}$ muhfahroyin@yahoo.com, ${ }^{2}$ lepi22evolusi@gmail.com
}

\begin{abstract}
The Covid-19 pandemic became an obstacle to social and economic activities, including education and learning especially. In the normal condition, the learning usually carried out classically turns into online in the pandemic era. In other words, the learning must be carried out, even during a pandemic. The research objective was to analyze the profile of learning resources through a learning community based on a virtual collaborative learning model in the Covid-19 pandemic. The research was Research and Development by using the 4D Model Thiagarajan, reinforce in the validation and evaluation based on virtual collaborative learning. This research was conducted in senior high school biology study in the biology education department of teacher training and education faculty of Muhammadiyah Metro University. The subjects of this study were 32 students divided into 13 virtual groups. One group has a role as developer of the learning materials, and another group has the role of validator and evaluator of the learning materials. The research would know the feasibility of a profile of learning materials assessed using virtual collaborative learning. The data collection techniques using a virtual observation sheet. The data collection instrument consisted of guidelines for observing the profile of learning materials. Data analysis was carried out descriptively using the indicators of learning materials. The results of the research show that the learning materials developed have a suitable profile for use. The Average score for the assessment of learning materials was 82,36. All profile indicators are showing good results. Validation and evaluation using virtual collaborative learning effectively assess a learning resource. Through this collaborative learning, the learning community during the Covid-19 pandemic was carried out well.
\end{abstract}

Kata kunci: Bahan ajar biologi, learning community, pembelajaran kolaboratif, pembelajaran virtual, pandemi Covid-19

\section{PENDAHULUAN}

Tahun 2020 terjadi perubahan aspek kesehatan dan menuntut perubahan perilaku masyarakat yang disebabkan oleh pandemi Covid-19. Menurut WHO pandemi Covid-19 ini memiliki skala global hampir merata di seluruh negara di dunia (WHO, 2020)). Pandemi ini mempengaruhi proses kognisi, emosi dan perilaku manusia dalam kehidupan di masyarakat, sehingga diperlukan kewaspadaan akan bahaya yang ditimbulkannya (Agung, 2020; Muhfahroyin dkk, 2020). Dalam bidang pendidikan, terutama pembelajaran harus menyesuaikan dengan kondisi ini. Pembelajaran dilakukan secara online untuk pendidikan dasar sampai perguruan tinggi (Muhammadiyah, 2020). Pembelajaran online berbasis e-learning telah banyak dilaksanakan sebelum masa pandemi Covid-19 dan hasilnya menunjukkan efektivitas yang tinggi untuk aspek pengetahuan dan aktivitas virtual (Dhawan, 2020). Pembelajaran dengan media virtual ini telah banyak dibahas seiring berkembangnya era revolusi industri 4.0. Dengan pembelajaran ini, komunikasi dan interaksi berbasis TIK yang meminimalisir interaksi antar siswa secara langsung (Muhfahroyin \& Susanto, 2018). Terkait dengan pandemi 
Covid-19, pembelajaran jarak jauh lebih memberikan perlindungan pada para siswa karena antar siswa tidak saling berdekatan, sehingga tidak berpotensi menularkan penyakit yang mungkin ada pada salah satu atau beberapa siswa. Kondisi menjaga jarak ini menjadi salah satu pilar protocol kesehatan. Yanti dkk (2020) menyatakan bahwa kepatuhan masyarakat terhadap kebijakan social distancing merupakan bagian untuk mengontrol pandemi Covid-19. Dengan pendekatan pembelajaran seperti ini, maka pembelajaran tetap berjalan sesuai visi dan misi bidang pendidikan.

Pembelajaran dapat dilaksanakan dengan metode dan pendekatan yang bervariasi, sehingga pembelajaran berjalan dengan prinsip efisien, efektif, dan optimal (Silberman, 2001; Basilaia, 2020). Mukhtar dan Iskandar (2012) menyatakan pembelajaran efektif dapat memanfaatkan teknologi informasi dan komunikasi. Pendidik dan peserta didik dapat berinteraksi dengan difasilitasi teknologi komunikasi online dan memanfaatkan platform e-learning (Muhfahroyin dan Susanto, 2018).

Salah satu pembelajaran biologi adalah mengkaji dan menelaah bahan ajar yang akan digunakan sebagai sumber belajar siswa. Mahasiswa pendidikan biologi memiliki capaian pembelajaran yang terkait dengan kemampuan menelaah bahan ajar ini. Sebagai calon guru, mahasiswa pendidikan biologi harus mampu mengembangkan bahan ajar sekaligus menelaah dan menilai kelayakan bahan ajar tersebut. Bahan ajar yang dikembangkan kontekstual sangat membantu siswa untuk mempermudah mempelajari konsep-konsep atau prinsip-prinsip sains yang lebih tinggi (Depdiknas, 2002; Johnson, 2007). Pemahaman sains yang memadai akan membantu siswa mampu memecahkan permasalahannya yang berkaitan dengan sains dalam kehidupan sehari-hari serta mampu melakukan langkah-langkah pengembangan lebih lanjut berupa pemanfaatkan konsep-konsep sains tersebut untuk kepentingan hidupnya yang merupakan landasan berpikir bagi siswa dalam mengatasi permasalahan yang dapat ditemukan dalam kehidupan sehari-hari. Bila bermaknanya pembelajaran sains telah sampai pada aspek sikap, moral, dan kepedulian peserta didik, maka jiwa yang berkarakter akan terbentuk seiring dengan pembelajaran yang diselenggarakan. Lebih lanjut Muhfahroyin (2010) menjelaskan bahwa dengan pembelajaran yang berorientasi konstruktivisme pada pembelajaran biologi dapat memfasilitasi siswa meningkatkan pengetahuan dan kemampuan berpikir kritis. Mengkaji dan menelaah sebuah bahan ajar dapat dilakukan secara bersama dalam kelompok-kelompok belajar yang mengacu pada learning community (Muhfahroyin \& Santoso, 2019). Pembelajaran dengan cara kolaboratif akan terjadi scaffolding, yaitu siswa saling membantu untuk mencapai keberhasilan meraih kompetensi tertentu dengan bantuan sesama teman dalam kelompok belajar.

Pembelajaran kolaboratif menuntut peserta didik untuk dapat bertanggung jawab atas belajar mereka sendiri dan berusaha menggali informasi yang berhubungan dengan bekal kompetensi yang harus dipahami. Dalam pembelajaran kolaboratif, guru berperan sebagai fasilitator bagi semua siswa dalam kelompok belajar, sehingga dipastikan semua siswa benar-benar belajar membentuk learning community (Saito \& Atencio, 2015; Paige, 2018). Hasil proses pembelajaran kolaboratif ini dilakukan penilaian oleh sesama siswa yang ada dalam kelas yang sama. Luzet (2013) menyatakan bahwa pembelajaran kolaboratif mendasarkan pada teori Zone of Proximal Development (ZPD) dan scaffolding, siswa saling membantu untuk mencapai keberhasilan meraih 
kompetensi tertentu dalam kelompok belajar.

Karakteristik belajar kolaboratif yang terbentuk yaitu siswa belajar dalam satu kelompok dan memiliki rasa ketergantungan dalam proses belajar, penyelesaian tugas kelompok mengharuskan semua anggota bekerja bersama, interaksi tatap muka antar anggota kelompok, masing-masing siswa bertanggung jawab terhadap tugas yang telah disepakati, siswa belajar keterampilan komunikasi interpersonal, peran guru sebagai fasilitator, sharing pengetahuan antar siswa, pengelompokkan secara heterogen (Brandt \& Messeter, 2004); ; (Muhfahroyin \& Santoso, 2019). Selain itu menurut Olivares (2005) dengan pembelajaran kolaboratif siswa terlatih berkomunikasi dan berpikir kritis. Kebersamaan siswa dalam kelompok berpikir kritis menghasilkan pemahaman tingkat tinggi yang dapat dimiliki setiap anggota kelompok.

Dari rasional kajian ini, sangat penting dikaji dan ditelaah profil bahan ajar yang dikembangkan melalui pembelajaran kolaboratif virtual untuk memfasilitasi dan memberdayakan potensi mahasiswa. Kajian dan telaah profil bahan ajar berbasis tekstual klasikal konvensional sudah banyak dikembangkan dan dikaji, tetapi proses pengembangan dan telaah bahan ajar secara virtual belum optimal dikembangkan.

\section{METODE}

Jenis penelitian ini adalah Research and Development ( $\mathrm{R}$ and $\mathrm{D})$ yang diadaptasi dari Thiagarajan (1985), dengan langkah-langkah pengembangan sebagai berikut.

\section{Define (Pendefinisian)}

Tahap define (pendefinisian) ini dilakukan dengan analisis konsep dan analisis kebutuhan mengenai bahan ajar yang dikembangkan.

\section{Design (Perancangan)}

Design (perancangan) dilakukan untuk menghasilkan rancangan bahan ajar yang berorientasi virtual leaning community, sebelum dilakukan tahap pengembangan. Tahap ini dilakukan untuk merancang desain, tujuan, referensi dan kedalaman materi.

\section{Develop (Pengembangan)}

Tahap develop (pengembangan) adalah pelaksanaan pengembangan bahan ajar. Kegiatan ini merupakan perwujudan dari kegiatan perancangan. Pengembangan dilaksanakan dengan menyusun dan memvalidasi bahan ajar. Validasi dilakukan dengan cara telaah oleh 13 yang menilai dengan lembar penilian berisi 15 indikator profil bahan ajar.

\section{Disseminate (Penyebarluasan)}

Tahap $\begin{array}{r}\text { disseminate } \\ \text { dilakukan }\end{array}$
menyebarluasan) tidak wingat keterbatasan waktu, biaya,
dan keterbatasan komunikasi dengan
stakeholder di masa pandemi Covid-19.

\section{HASIL DAN PEMBAHASAN}

Profil bahan ajar kontekstual yang dikembangkan dan ditelaah secara kolaboratif virtual dideskripsikan sama dengan pengembangan bahan ajar konvensional, namun proses pengembangan dan telaahnya dilakukan secara virtual kolaboratif. Pengembangan bahan ajar dilakukan oleh Kelompok 3 dengan interaksi dalam jaringan atau virtual kolaboratif. Sedangkan 12 kelompok lainnya menjadi penilai dan penelaah kelayakan bahan ajar. Untuk mengetahui profil bahan ajar tersebut, telaah validasi dilakukan terhadap aspek sebagai berikut. 1) Kesesuaian materi dengan tujuan. 2) Kesesuaian dengan perkembangan IPTEKS. 3) Akurasi materi. 4) Sistematika penyajian materi. 5) Kejelasan petunjuk belajar. 6) Materi mudah dipahami. 7) Kesesuaian materi dengan peserta didik. 8) Desain dan tata letak. 9) Kecukupan dan kedalaman materi. 10) Keterkinian. 11) Kontekstual. 
12) Menumbuhkan rasa ingin tahu. 13) Merangsang berpikir kritis. 14) Aspek kebahasaan. 15) Melatih kerjasama dalam belajar. Skor hasil telaah dan penilaian dapat dilihat pada Tabel 1 . Visualisasi gafis dapat dilihat pada Gambar 1.

Berdasarkan Tabel 1 dan Gambar 1 dapat dideskripsikan sebagai berikut. 1) Kesesuaian materi dengan tujuan memperoleh rata-rata skor kelayakan 82,83. 2) Kesesuaian dengan perkembangan IPTEKS memperoleh rata-rata skor kelayakan 82,25. 3) Akurasi materi memperoleh rata-rata skor kelayakan79,17. 4) Sistematika penyajian materi memperoleh rata-rata skor kelayakan 82,83. 5) Kejelasan petunjuk belajar memperoleh rata-rata skor kelayakan 86,42. 6) Materi mudah dipahami memperoleh rata-rata skor kelayakan 88,08. 7) Kesesuaian materi dengan peserta didik memperoleh ratarata skor kelayakan 81,42. 8) Desain dan tata letak memperoleh rata-rata skor kelayakan 80,92. 9) Kecukupan dan kedalaman materi memperoleh rata-rata skor kelayakan 81,08. 10) Keterkinian memperoleh rata-rata skor kelayakan 85,33. 11) Kontekstual memperoleh ratarata skor kelayakan 80,42. 12) Menumbuhkan rasa ingin tahu memperoleh rata-rata skor kelayakan 79,92 13) Merangsang berpikir kritis memperoleh rata-rata skor kelayakan 78,92. 14) Aspek kebahasaan memperoleh rata-rata skor kelayakan 83,25. 15) Melatih kerjasama dalam belajar memperoleh rata-rata skor kelayakan 82,58.

Tabel 1. Skor hasil telaah dan penilaian kelompok terhadap bahan ajar.

\begin{tabular}{|c|c|c|c|c|c|c|c|c|c|c|c|c|c|c|}
\hline \multirow{2}{*}{ No. } & \multirow{2}{*}{$\begin{array}{c}\text { Indikator Profil } \\
\text { Bahan Ajar }\end{array}$} & \multicolumn{12}{|c|}{ Kelompok Penelaah } & \multirow[t]{2}{*}{ Rata-rata } \\
\hline & & 1 & 2 & 4 & 5 & 6 & 7 & 8 & 9 & 10 & 11 & 12 & 13 & \\
\hline 1 & $\begin{array}{l}\text { Kesesuaian materi } \\
\text { dengan tujuan }\end{array}$ & 82 & 80 & 87 & 87 & 86 & 82 & 85 & 80 & 86 & 80 & 81 & 78 & 82,83 \\
\hline 2 & $\begin{array}{l}\text { Kesesuaian dengan } \\
\text { perkembangan } \\
\text { IPTEKS }\end{array}$ & 80 & 81 & 83 & 82 & 80 & 83 & 85 & 86 & 81 & 82 & 83 & 81 & 82,25 \\
\hline 3 & Akurasi materi & 83 & 80 & 80 & 80 & 79 & 80 & 78 & 77 & 80 & 77 & 78 & 78 & 79,17 \\
\hline 4 & $\begin{array}{l}\text { Sistematika } \\
\text { penyajian materi }\end{array}$ & 80 & 80 & 83 & 80 & 84 & 82 & 82 & 86 & 84 & 83 & 84 & 86 & 82,83 \\
\hline 5 & $\begin{array}{l}\text { Kejelasan petunjuk } \\
\text { belajar }\end{array}$ & 80 & 90 & 86 & 87 & 88 & 89 & 85 & 88 & 88 & 87 & 85 & 84 & 86,42 \\
\hline 6 & $\begin{array}{l}\text { Materi mudah } \\
\text { dipahami }\end{array}$ & 90 & 80 & 89 & 93 & 89 & 88 & 88 & 87 & 87 & 89 & 90 & 87 & 88,08 \\
\hline 7 & $\begin{array}{l}\text { Kesesuaian materi } \\
\text { dengan peserta } \\
\text { didik }\end{array}$ & 80 & 85 & 80 & 83 & 86 & 81 & 82 & 83 & 81 & 79 & 77 & 80 & 81,42 \\
\hline 8 & $\begin{array}{l}\text { Desain dan tata } \\
\text { letak }\end{array}$ & 84 & 80 & 81 & 80 & 82 & 81 & 83 & 80 & 80 & 80 & 79 & 81 & 80,92 \\
\hline 9 & $\begin{array}{l}\text { Kecukupan dan } \\
\text { kedalaman materi }\end{array}$ & 80 & 82 & 80 & 82 & 82 & 83 & 82 & 83 & 82 & 80 & 79 & 78 & 81,08 \\
\hline 10 & Keterkinian & 80 & 80 & 88 & 87 & 88 & 87 & 86 & 88 & 88 & 84 & 85 & 83 & 85,33 \\
\hline 11 & Kontekstual & 79 & 80 & 80 & 77 & 80 & 83 & 80 & 84 & 82 & 82 & 80 & 78 & 80,42 \\
\hline 12 & $\begin{array}{l}\text { Menumbuhkan } \\
\text { rasa ingin tahu }\end{array}$ & 82 & 80 & 80 & 87 & 79 & 78 & 81 & 80 & 77 & 78 & 78 & 79 & 79,92 \\
\hline 13 & $\begin{array}{l}\text { Merangsang } \\
\text { berpikir kritis }\end{array}$ & 80 & 76 & 80 & 87 & 78 & 80 & 75 & 77 & 82 & 77 & 79 & 76 & 78,92 \\
\hline 14 & $\begin{array}{l}\text { Melatih } \\
\text { keterampilan } \\
\text { proses sains } \\
\end{array}$ & 82 & 80 & 80 & 87 & 88 & 81 & 82 & 84 & 86 & 84 & 83 & 82 & 83,25 \\
\hline
\end{tabular}


MUHFAHROYIN \& A. LEPIYANTO, TELAAH BAHAN...

\begin{tabular}{|c|c|c|c|c|c|c|c|c|c|c|c|c|c|c|}
15 & $\begin{array}{l}\text { Melatih kerjasama } \\
\text { dalam belajar }\end{array}$ & 80 & 80 & 85 & 87 & 81 & 82 & 83 & 82 & 83 & 82 & 80 & 86 & 82,58 \\
\hline & Rata-rata & 81 & 81 & 83 & 84 & 83 & 83 & 82 & 83 & 83 & 82 & 81 & 81 & 82,36 \\
\hline
\end{tabular}

Skor Kelayakan

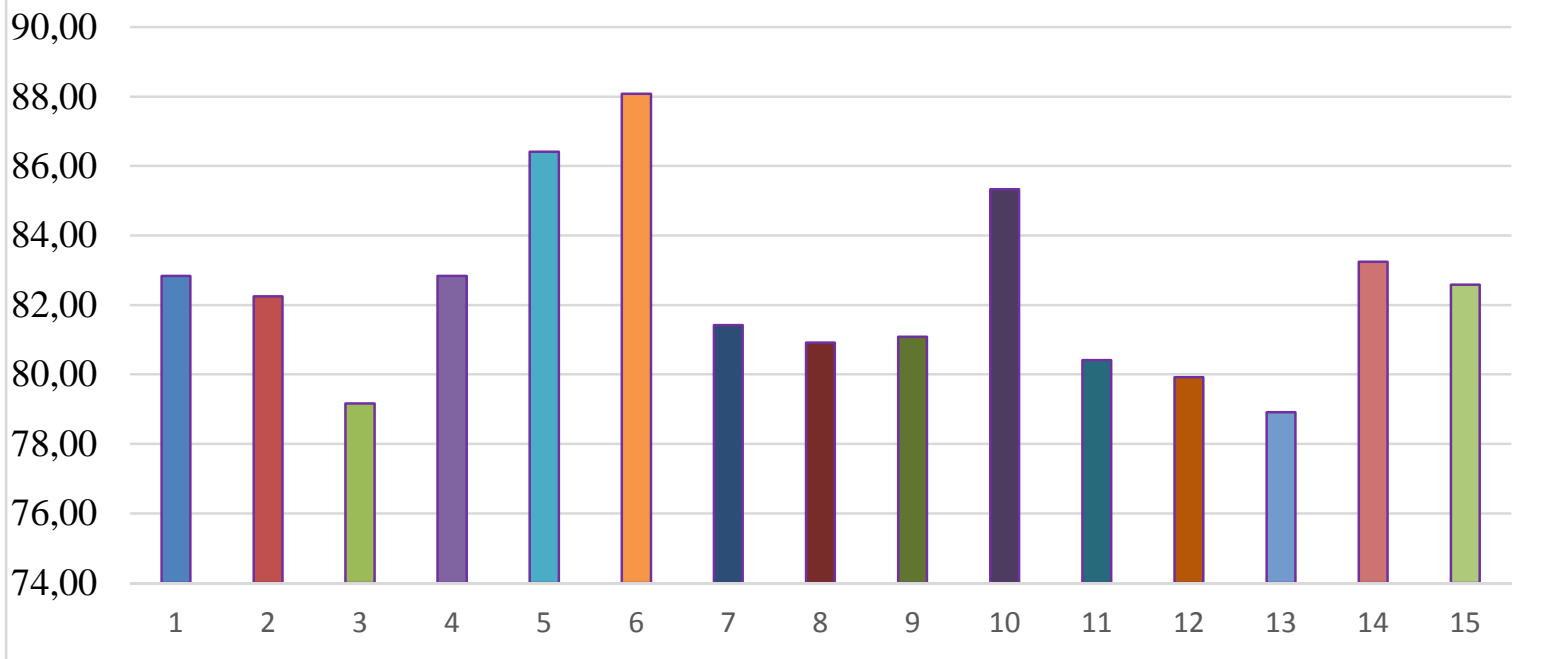

Gambar 1. Rata-rata skor telaah dan penilaian bahan ajar.

Profil bahan ajar yang dikembangkan dan ditelaah dalam pembelajaran kolaboratif virtual ini dinyatakan layak dengan rata-rata $82,36 \%$ sesuai dengan kebutuhan rancangan perangkat pembelajaran kontekstual yang dilaksanakan dengan media online (Muhfahroyin \& Susanto, 2018). Kelayakan sebuah perangkat bila mencapai minimal 63,1\% (Sugiyono, 2008). Selanjutnya Muhfahroyin (2010) dan Muhfahroyin (2016) mengemukakan bahwa dalam mempelajari biologi, peserta didik perlu dikenalkan dengan kondisi riil di lapangan agar siswa memahami seluk beluk lingkungan sebagai sumber belajar biologi. Bahan ajar sebagai bentuk material yang digunakan untuk membantu siswa dalam belajar harus memberikan penguatan pengetahuan dan keterampilan. Bahan ajar harus memenuhi syarat kelayakan dari berbagai aspek substansi, karena selama ini banyak bahan ajar yang umumnya hanya berisi informasi bidang studi saja dan tidak terorganisasi dengan baik (Lestari, 2013). Tingkatan berpikir yang diharapkan dari siswa dalam mempelajari biologi kontekstual adalah dalam tingkatan berpikir runut dan memadai, bukan sekadar tingkat hafalan materi, tetapi pengamatan kondisi lingkungan yang sebenarnya. Bahan ajar juga harus mampu mengembangkan kemampuan berpikir kritis dalam pembelajaran biologi yang menekankan pada hand on activities dan mind on activities.

Dalam aspek keterampilan proses sains, bahan ajar biologi sangat strategis untuk meningktkan keterampilan proses sains siswa. Bahan ajar yang dikembangkan sebaiknya memfasilitasi siswa belajar guna meningkatkan keterampilan proses sains yaitu mengamati, mengklasifikasi, mengukur, mengkomunikasikan, menafsirkan, dan menyimpulkan (Gega, 1994; Asih, 2015, Muhfahroyin, 2016). Senada dengan hal tersebut, Blanchard (2001) dan Muhfahroyin (2010) menyampaikan bahwa dalam pembelajaran kontekstual, siswa mengaitkan konsep pembelajaran teoritik dengan kenyataan di lapangan. Pembelajaran di lapangan membutuhkan intrumen kegiatan lapang yang operasional dan mudah dilaksanakan (Johnson, 2007; Muhfahroyin \& Santoso, 2019). Dalam pembelajaran kontekstual, peserta didik 
juga terlatih keterampilan proses sains. Oleh karena itu dalam profil bahan ajar sebaiknya memasukkan aspek kontekstual dan keterampilan proses sains.

Pembelajaran yang menekankan keterampilan proses sains melatih siswa benar-benar melakukan hal-hal yang dilakukan oleh seorang ilmuwan, seperti pengamatan, pengukuran, pengidentifikasian dan pengendalian, dan percobaan (Bell, 2007). Keterampilan proses sains merupakan pendekatan yang ditempuh para ilmuwan dalam usaha memecahkan misteri-misteri alam (Ramig dkk., 2002; Rezba dkk, 2008). Selanjutnya, Muhfahroyin (2016) menyatakan bahwa meningkatnya keterampilan proses membuat siswa melaksanakan pembelajaran dengan pengembangan metode ilmiah, menemukan dan mengembangkan fakta serta konsep yang ditemukan, sehingga pembelajaran lebih bermakna (meaningful), konstruktivistik, dan kontekstual (Muhfahroyin \& Oka, 2021). Pembelajaran bermakna ini juga diungkapkan oleh Ausubel (1968) bahwa pembelajaran yang menghubungkan dengan kenyataan sehari-hari akan lebih bermakna bagi peserta didik disbanding pembelajaran berbasis tekstual saja.

Bahan ajar yang dikembangkan dan ditelaah dalam pembelajaran kolaboratif virtual sebaiknya memfasilitasi siswa belajar guna meningkatkan pemahaman dan kemampuan berpikir kritis dalam kondisi kontekstual. Senada dengan hal tersebut, Blanchard (2001) menyampaikan bahwa dalam pembelajaran kontekstual, siswa mengaitkan konsep pembelajaran teoritik dengan kenyataan di lapangan. Pembelajaran di lapangan membutuhkan intrumen kegiatan lapang yang operasional dan mudah dilaksanakan (Johnson, 2007).

Profil bahan ajar yang memenuhi aspek-aspek penting seperti berorientasi kontekstual, melatih keterampilan proses sains, memberdayakan kemampuan berpikir kritis, dan melatih kerja sama ini layak diimplementasikan dalam pembelajaran biologi sekolah menangah. Melalui bahan ajar kontekstual, pembelajaran akan lebih bermakna. Belajar biologi tidak hanya di ruang kelas, tetapi juga dapat dilakukan di lingkungan sekitar (Yuniastuti, 2013). Selanjutnya Muhfahroyin \& Oka (2017; 2021) menyatakan bahwa melalui wahana ini, mahasiswa mendapatkan pengalaman langsung dari lingkungan tentang substansi kajian yang relevan dengan mata kuliah yang diselenggarakan, selain itu, mahasiswa mendapatkan pengalaman belajar langsung terkait kondisi lingkungan yang membutuhkan karakter kepedulian lingkungan. Bahan ajar yang memberdayakan kerjasama juga sangat penting untuk mengembangkan learning community. Melalui sebuah bahan ajar, siswa akan mengembangkan pengetahuannya. Selanjutnya pengetahuan yang telah dimiliki oleh siswa direfleksikan kembali untuk pengembangan lebih lanjut melalui pembelajaran bersama membentuk learning community, sehingga antar siswa dapat terjadi hubungan saling belajar (Saito, \& Atencio, (2015). Senada dengan hal tersebut Senduk (2003) dan Silberman (2001) menyatakan melalui pembelajaran aktif, belajar kerjasama ini secara kontekstual akan memunculkan curah gagasan, motivasi, dan inovasi yang terjadi karena adanya interaksi dan kerjasama yang anggota kelompok siswa. Dengan kompleksnya ranah yang dituju dalam sebuah bahan ajar, maka akan mengoptimalkan kemampuan siswa secara komprehensif pada ranah kognitif, afektif, dan psikomotor.

\section{KESIMPULAN DAN SARAN}

Berdasarkan profil bahan ajar yang dikembangkan oleh pengembang dapat dinyatakan bahwa bahan ajar tersebut layak digunakan. Rata-rata skor kelayakan adalah 82,36. Bahan ajar memenuhi aspek kecukupan materi, berorientasi kontekstual, melatih keterampilan proses sains, memberdayakan kemampuan 
berpikir kritis, dan melatih kerja sama. Bahan ajar layak diimplementasikan dalam pembelajaran biologi sekolah menengah. Selanjutnya, dalam pengembangan bahan ajar dan telaah bahan ajar dapat dilaksanakan dalam pembelajaran biologi dengan memanfaatkan teknologi informasi dan komunikasi mealui pembelajaran kolaboratif virtual untuk memfasilitasi learning community.

\section{DAFTAR RUJUKAN}

Agung, I. M. 2020. Memahami Pandemi COVID-19 dalam Perspektif Psikologi Sosial. Psikobuletin, Buletin Ilmiah Psikologi. Volume 1 Nomor 2. 68-84.

Asih, T. 2015. Pengembangan Model Panduan Pembelajaran Keterampilan Proses Sains Biologi SMA/MA. Jurnal Pendidikan Biologi Bioedukasi Vol. 6 No. 1 Mei 2015. Lampung: Universitas Muhammadiyah Metro.

Ausubel. 1968. Educational Psichology: a Cognitive View. New York: Holt, Rinehart, and Winston.

Basilaia, G. (2020). Replacing the Classic Learning Form at Universities as an Immediate Response to the COVID19 Virus Infection in Georgia. International Journal for Research in Applied Science and Engineering Technology, 8(3), 101-108. https://doi.org/10.22214/ijraset.2020. 3021.

Bell, R.L. 2007. Teaching the Nature of Science through Process Skills. Pearson Publisher.

Blanchard, A. 2001. Contextual Teaching and Learning. @B.E.S.T.

Brandt, E. and Messeter, J. 2004. Facilitating collaboration through design games. Proceedings of the eighth conference on Participatory design: Artful integration: interweaving media, materials and practices. Volume 1 Pages 121-131. https://doi.org/

$10.1145 /$ 1011870.1011885
Dhawan, S. 2020. Online Learning: A Panacea in the Time of COVID-19 Crisis. Journal of Educational Technology Systems, 49(1), 5-22. https://doi.org/ $10.1177 /$ 0047239520934018.

Depdiknas. 2002. Pendekatan Kontekstual (Contextual Teaching and Learning). Jakarta: Ditjen Dikdasmen Depdiknas.

Gega, P. C. 1994. Concepts and Experiences in Elementary School Science. New York: Macmillan Publishing Company.

Johnson, E. B. 2007. Contextual Teaching and Learning. Bandung: MLC.

Lestari, I. 2013. Pengembangan Bahan Ajar Berbasis Kompetensi.Jakarta: Akademia Permata.

Luzet, G. 2013. Collaborative Learning Pocketbook. UK: Teachers' Pocketbooks Publisher.

Muhammadiyah. 2020. Himbauan kepada Pimpinan Perguruan Tinggi untuk dapat berbagi/sharing materi pembelajaran daring dengan membuka akses pembelajaran daring atau pembelajaran jarak jauh (PJJ). (n.d.). https://dikti.kemdikbud.go.id /pengumuman /himbauan-kepadapimpinan-perguruan-tinggi-untukdapat-berbagi-sharing-materipembelajaran-daring-denganmembuka-akses-pembelajarandaring-atau-pembelajaran-jarakjauh-pjj/

Muhfahroyin. 2010. Memberdayakan Kemampuan Berpikir Kritis Siswa Melalui Pembelajaran Konstruktivistik. Jurnal Pendidikan dan Pembelajaran. 9(1). 88-93 
Muhfahroyin and Oka, A. A. 2017. Improving Post-graduate Students Learning Activities through Lesson Study in Learning Forest-Prototype. Biosaintifika: Journal of Biology \& Biology Education. Vol 9, No 2.

Muhfahroyin and Susanto, E. 2018. The Implementation of E-Learning to Improve Students' Virtual Activities. Journal of Physics: Conference Series. 1114, 012039.

Muhfahroyin and Santoso, H. 2019. The Effect of STAD and TPS Integration in Biology Learning Toward the Students Cognitive Achievement. International Journal of Innovation, Creativity and Change. Volume 5, Issue 4.

Muhfahroyin and Oka, A. A. 2021. Utilization of the learning forest prototype to increase the student's careness character of the environment through the Lesson Study for Learning Community (LSLC). IOP Conference Series: Earth and Environmental Science. 747, 012113.

Olivares, O. J. 2005. Collaborative critical thinking: Conceptualizing and defining a new construct from known constructs. Issues in Educational Research. Volume 15.

Paige, S. M., Wall, A. A., Marren, J. J., Dubenion, B., \& Rockwell, A. 2018. The Learning Community Experience in Higher Education: High-Impact Practice for Student Retention. Journal of College Student Retention: Research, Theory \& Practice. 20(4). 536-539.

Ramig, J.E., Bailer, J., Ramsey, J.M. 2002. Teaching Science Process Skills. School Specialty Children's Publishing.

Rezba, R.J., Sprague, C. R., Mcdonnough, J.T. 2008. Learning and Assessing Science Process Skills. Kendall Hunt Publisher.
Saito, E Murase, M., Tsukui, A., Yeo, J. 2015. Lesson Study for Learning Community A guide to sustainable school reform. 1st Edition. Routledge Publisher.

Saito, E. \& Atencio, M. 2015. Lesson study for learning community (LSLC): conceptualising teachers' practices within a social justice perspective. Discourse: Studies in the Cultural Politics of Education. 36(6). 795-807. DOI: 10.1080/01596306. 2014.968095

Silberman, M. 2001. Active Learning, 101 Strategi Pembelajaran Aktif. Yogyakarta: Yappendis.

Sugiyono. 2008. Metode Penelitian Pendidikan (Pendekatan Kuantitatif, Kualitatif, dan R\&D). Bandung: Alfabeta.

Thiagarajan, S. 1985. Development Research Model in Education. Boston: Allyn and Bacon.

Yanti, B. Eko Mulyadi, Wahiduddin, Revi Gama Hatta Novika, Yuliana Mahdiyah Da'at Arina, Natalia Sri Martani, Nawan. 2020. Pengetahuan, Sikap, dan Perilaku Masyarakat terhadap Kebijakan Jaga Jarak sebagai Cara Pencegahan Penularan COVID-19 di Indonesia. Jurnal Administrasi Kesehatan Indonesia. Volume 1 Nomor 8 Special Issue 2020. 